\title{
CHANGES IN SERUM LYSOZYME AND BACTERICIDAL ACTIVITY IN GROWING HEIFERS OF DIFFERENT BREEDS
}

\author{
Viktor I. EREMENKO1 and Elena G. ROTMISTROVSKAYA² \\ ${ }^{1}$ Head of the Department, Ph.D., Biology, Professor, I.I. Ivanov Kursk State Agricultural Academy, Kursk, Russia \\ 2Senior Lecturer, Ph.D. in Biology, I.I. Ivanov Kursk State Agricultural Academy, Kursk, Russia \\ Email: vic.eriomenko@yandex.ru; (D) ORCiD: 0000-0003-3780-7724 \\ supporting Information
}

ABSTRACT: The study presents the results of a study of the bactericidal and lysozyme activity of blood serum of heifers of different breeds. The experiment involved 4 groups of heifers, 10 heads in each group: 1) Black-and-white Holstein; 2) Simmental; 3) Aberdeen-Angus; and 4) crosses of Simmental and Aberdeen-Angus breeds. Animals of all groups were kept in the same feeding and housing conditions. During the experiments, the animals were fed according to generally accepted standards. Blood was taken from animals from the tail vein in the morning before the first feeding in compliance with the aseptic rules. It was found that with an increase in gestation, the activity of serum bactericidal activity (SBA) and serum lysozyme activity (SLA) in the blood of heifers gradually increases.in conclusion, during pregnancy, the level of SBA and SLA in the blood of heifers depended on the month of pregnancy and the breed of animals. During pregnancy, hybrid heifers have higher levels of SBA and SLA, and relatively low levels of SBA and SLA are observed in Black-and-White, Simmental and Aberdeen Angus heifers.

Keywords: Aberdeen-Angus, Bactericidal, Heifer, Lysozyme activity, Simmental.

\section{INTRODUCTION}

Increasing the productivity of farm animals is the key challenge of modern animal husbandry (Eremenko and Kretova, 2007). To achieve this goal, in addition to improving the quality of feeding and improving the management of the industry, it is necessary to carry out systematic selection work on the most important inherited traits of animals (Rauw and GomezRaya, 2015; Balzani and Hanlon, 2020). To improve the productive qualities of cattle, it is necessary to study in more detail the mechanism of the formation of natural resistance, and its relationship with the future productive qualities of animals, and in the future to recommend the most resistant breeds of cattle for their use in breeding work (Eremenko and Polianskii, 2013; Marshal et al., 2019).

The main indicator of natural resistance of livestock is the indicators of bactericidal and lysozyme activity of blood serum (Zhou et al., 2019). This indicator is widely used in fish health detection and aquaculture (Das and Sahoo, 2014; Panase et al., 2017). Especially in dairy cows it's documented that lyzozyme level in milk is an important indicator for immune status and it's differed with breeds of cows (Król et al., 2010).

Thus, serum bactericidal activity (SBA) and serum lysozyme activity (SLA) are a combined manifestation of the body's natural defenses (Carroll and Jasper, 1977). SLA can be different in depends on breed of farm animal (Sotirov et al., 2007), and it's documented in local studies (Sotirov et al., 2006; 2007). The study of these mechanisms will make it possible to purposefully use these indicators in the selection of cattle (Król et al., 2010). Aim of present study is to determination of these indicator activities in different breeds of cows.

\section{MATERIALS AND METHODS}

The studies were carried out on Black-and-White Holstein, Simmental, Aberdeen-Angus and crossbred heifers of Blackand-White breeds. Heifers were analogous in age and gestational age, 10 heads in each group. They were grown in the same conditions, which ensured their normal growth, development and, subsequently, milk and meat productivity, characteristic of each breed. During the experiments, the animals were fed according to generally accepted standards. Blood was taken from animals from the tail vein in the morning before the first feeding in compliance with the aseptic rules. SBA and SLA indices were determined according to generally accepted methods. The obtained research results were subjected to biometric processing by variation statistics using Microsoft Office Excel.

\section{Statistical analysis}

The One-way AOVA method used for statistical comparison of treatments. For comparison of means, SAS software, version $10(P<0.05)$ was used, and Duncan multiple range test for comparison of means. Experimental groups consisted: 1-Black-and-White Holstein, 2-Simmental, 3-Aberdeen-Angus and 4crossbred heifers of Black-and-White (n: 10). 


\section{Ethical approval}

The in vivo and in vitro studies were approved by ethical committee of department of Biology, I.I. Ivanov Kursk State Agricultural Academy of Russia.

\section{RESULTS}

\section{Blood serum bactericidal activity (SBA)}

SBA indices in the first month of pregnancy in all groups were within normal limits and did not differ significantly across groups. The data shown in Figure 1 show that in the first month of lactation, the bactericidal activity of blood serum in heifers of different breeds was between $82.7 \pm 3.8 \%$ and $89.4 \pm 4.2 \%$.

By the second month of pregnancy, this indicator in all compared breeds of heifers increased slightly and was

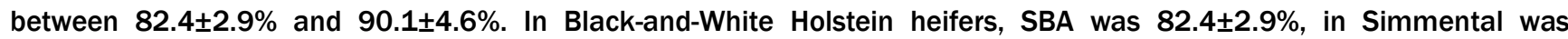
$83.3 \pm 3.3 \%$, in Aberdeen-Angus was $90.1 \pm 4.6 \%$ and in crossbred animals was $89.0 \pm 3.7 \%$. By the third month of pregnancy, SBA slightly increased in heifers of the first group to $82.7 \pm 2.8 \%$, in the second group to $83.7 \pm 3.1 \%$, in the fourth group to $89.3 \pm 4.5 \%$. In the group of Simmental heifers, SBA slightly decreased to $88.9 \pm 4.7 \%$. Later, at the 4 th and 5th months of pregnancy, the value of this indicator in all groups ranged between $82.3 \pm 3.1 \%$ and $92.4 \pm 4.0 \%$. The research found an increase in the bactericidal activity of blood serum by the 6th month of pregnancy in experimental animals. In Black-and-White Holstein, SBA was $80.0 \pm 2.9 \%$, in Simmental was $84.2 \pm 3.7 \%$, in Aberdeen-Angus was $88.8 \pm 4.2 \%$ and in crossbred heifers was $93.7 \pm 4.2 \%$. By the 9 th month of pregnancy, the bactericidal activity of blood serum continued to increase and amounted to $82.0 \pm 4.1 \%$ in Black-and-White Holstein, $87.4 \pm 3.7 \%$ in Simmental, $91.3 \pm 4.2 \%$ in Aberdeen-Angus, and $97.7 \pm 5.0 \%$ in crossbred heifers. During month 7 , 8, and 9 of gestation, crossbred animals showed statistically significant differences in relation to the data of the Black-and-White Holstein heifers $(P<0.05)$. Comparing the indicators of bactericidal activity of blood serum between the experimental groups of heifers, it should be noted that before the $9^{\text {th }}$ month of pregnancy, this indicator was slightly higher in crossbred animals. Thus, the bactericidal activity of blood serum depends on the breed of heifers and the duration of pregnancy. Relatively low SBA was noted in Black-and-White Holstein in relation to the compared breeds of heifers, and higher SBA was noted in crossbred animals.

\section{Blood serum lysozyme activity (SLA)}

The lysozyme activity of blood serum in the first month of pregnancy in experimental heifers was approximately at the same level and amounted to $22.6 \pm 1.5 \%$ in Black-and-White Holstein, $22.3 \pm 1.5 \%$ in Simmental, $26.5 \pm 1.3 \%$ in Aberdeen-Angus, and $29.5 \pm 1.6 \%$ in crossbred heifers (Figure 2).
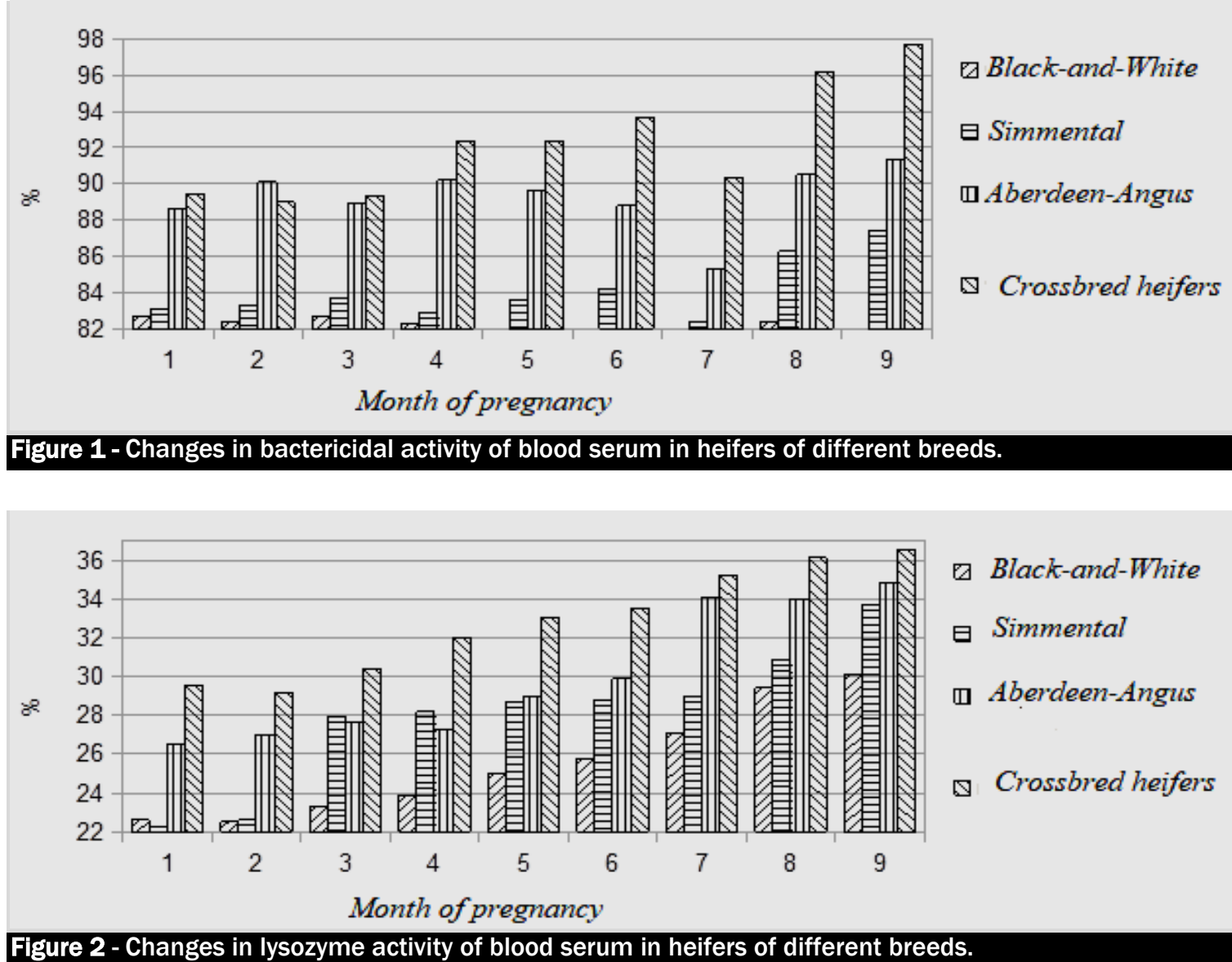
Statistically significant differences during the 1st month of gestation were noted between hybrid animals, Black-andWhite and Simmental heifers $(P<0.05)$. By the second month of pregnancy, the lysozyme activity of the blood serum of animals was also lower in Black-and-White Holstein. Crossbred animals showed the highest SLA level - 29.2 $\pm 1.3 \%$. Statistically significant differences at 2 months of gestation were noted between Black-and-White, Simmental breed of heifers and crossbred animals $(P<0.05)$. Mentioned differences in breeds (for SLA activity) has fully recognized in goat breeds by Marmaryan (2013).

Analyzing the data in Figure 2, it can be noted that by the third month of pregnancy, SLA was slightly lower in heifers of Black-and-White Holstein breed $-23.3 \pm 1.1 \%$. The highest level of SLA was also in crossbred animals $-30.4 \pm 1.4 \%$. In Black-and-White heifers, lysozyme activity during months 3, 4, and 5 of gestation was significantly lower in relation to crossbred animals $(P<0.05)$. In the second half of pregnancy, all breeds of animals showed an increase in lysozyme activity, especially pronounced these changes were noted in the Aberdeen Angus breed and crossbred animals. During the 6th months of pregnancy, SLA was $25.8 \pm 1.5 \%$ in Black-and-White Holstein, $28.8 \pm 1.4 \%$ in Simmental, $29.9 \pm 1.6 \%$ in Aberdeen-Angus, and $33.5 \pm 1.5 \%$ crossbred heifers.

Crossbred heifers had significantly higher lysozyme activity during the $6^{\text {th }}$ months of gestation in relation to Blackand-White Holstein and Simmental heifers $(P<0.05)$. The activity of lysozyme during the 9th month of pregnancy was $30.1 \pm 1.8 \%$ in Black-and-White Holstein; $33.7 \pm 1.8 \%$ in Simmental, $34.8 \pm 2.0 \%$ in Aberdeen-Angus, and $36.5 \pm 2.0 \%$ in crossbred animals. Black-and-white heifers at the end of pregnancy had a significantly lower activity than crossbred heifers $(P<0.05)$.

Thus, the lysozyme activity of blood serum in crossbred animals during all months of pregnancy exceeded those of the Simmental and especially the Black-and-White breed. This finding is in according to Puppel et al. (2019) who review and noted changes lysozyme activity in different breeds and in colostrum composition. An increase in SLA during pregnancy indicates an increase in serum lysozyme during pregnancy. This is obviously due to the evolutionary reaction of the nonspecific protection on the part of the mother to the birth of a viable calf.

\section{CONCLUSION}

With respect to the above it can conclude that with an increase in gestation, serum bactericidal activity (SBA) and serum lysozyme activity (SLA) of heifers gradually increases. During pregnancy, the level of SBA and SLA in the blood of heifers depended on the month of pregnancy and the breed of animals. During pregnancy, hybrid heifers have higher concentrations of SBA and SLA. During pregnancy, Black-and-White, Simmental, and Aberdeen Angus heifers have lower concentrations of SBA and SLA.

\section{DECLARATIONS}

Corresponding Author

E-mail: vic.eriomenko@yandex.ru; ORCID: 0000-0003-3780-7724

\section{Authors' Contribution}

Both authors contributed in research, experiments and writing, equally.

\section{Conflict of interests}

Authors declare no competing interests.

\section{REFERENCES}

Balzani A and Hanlon A (2020). Factors that influence farmers' views on farm animal welfare: a semi-systematic review and thematic analysis. Animals, 2020(10): 1524. Article link I DOI: https://doi.org/10.3390/ani10091524

Carroll EJ and Jasper DE (1977). Bactericidal activity of standard bovine serum against coliform bacteria isolated from udders and the environment of dairy cows. American Journal of Veterinary Research, 38(12): 2019-2022. Article link I Google Scholar.

Das S and Sahoo PK (2014). Markers for selection of disease resistance in fish: a review. Aquaculture International, 22 : $1793-1812$. Article link I DOI: https://doi.org/10.1007/s10499-014-9783-5

Król J, Litwińczuk Z, Brodziak A and Barłowska J (2010). Lactoferrin, lysozyme and immunoglobulin G content in milk of four breeds of cows managed under intensive production system. Polish Journal of Veterinary Sciences, 13(2): 357-361. Article link I PMID: 20731193.

Marmaryan G (2013). Study of milking efficiency, biochemical milk composition and hormonal blood parameters of Armenian goat breeds for the second lactation period. Iranian Journal of Applied Animal Science, 3(1): 101-104. Article Link I http://ijas.iaurasht.ac.ir/article_514246.html

Marshall K, Gibson JP, Mwai O, Mwacharo JM, Haile A, Getachew T, Mrode R and Kemp SJ (2019). Livestock genomics for developing countries - African examples in practice. Frontiers in Genetics, 10: 297. DOI: https://doi.org/10.3389/fgene.2019.00297 I Article link

Panase P, Saenphet S and Saenphet K (2007). Visceral and serum lysozyme activities in some freshwater fish (three catfish and two carps). Comparative Clinical Pathology, 26(1): 169-173. Article link I DOI: https://doi.org/10.1007/s00580-016-2362-6 
Puppel K, Gołębiewski M, Grodkowski G, Slósarz J, Kunowska-Slósarz M, Solarczyk P, Łukasiewicz M, Balcerak M, Przysucha T. (2019). Composition and factors affecting quality of bovine colostrum: a review. Animals. 9(12): 1070. Article link I DOI: https://doi.org/10.3390/ani9121070

Rauw WM and Gomez-Raya L (2015). Genotype by environment interaction and breeding for robustness in livestock. Frontiers in Genetics, 6: 310. Article link | DOI: https://doi.org/10.3389/fgene.2015.00310

Sotirov L, Semerdjiev V, Maslev T and Draganov B (2007). Breed-related differences in blood lysozyme concentration and complement activity in cows in Bulgaria. Revue de Médecine Vétérinaire, 158(5): 239-243. Article link

Sotirov L, Semerdjiev V, Maslev T and Gerchev G (2006). Breed and age-related differences in lysozyme concentrations and complement activity in rams. Trakia Journal of Sciences, 4 (3): 20-24. Article link

Zhou J, Xiong X, Yin J, Zou L, Wang K, Shao Y and Yin Y (2019). Dietary lysozyme alters sow's gut microbiota, serum immunity and milk metabolite profile. Frontiers in Microbiology, 10: 177. Article link I DOI: https://doi.org/10.3389/fmicb.2019.00177 